\title{
Joyce the Postmodernist: A Glance at Finnegans Wake
}

\author{
Javad Zangouei \\ English Department, Faculty of Literature and the Humanities, University of Birjand, Birjand 9717851367 \\ South Khorasan, IRAN \\ e-mail: javad.zangouei@gmail.com; jzangouei@birjand.ac.ir
}

\begin{abstract}
Postmodernism criticizes metanarratives. Modern metanarratives including Enlightenment, Hegelianism, and Marxism present general claims about knowledge and truth. Under postmodern condition metanarratives are damageable, criticizable, and finally negligible. In this essay metanarratives are explained and the incredulity towards them is traced. In Finnegans Wake, which is under postmodern condition, metanarratives are targets of Joyce's parody. In this novel, religion is bitterly criticized, Enlightenment is mocked, and Hegelianism and Marxism are disfigured. Joyce shows his incredulity towards metanarratives and employs postmodernist techniques. Finnegans Wake's world is postmodern.
\end{abstract}

Keywords: Black humor, Finnegans Wake, metanarratives, parody, pastiche, postmodernist fiction

\section{INTRODUCTION}

In The Postmodern Condition (1979/1984), Lyotard announces the eclipse of all modern metanarratives saying that the "incredulity towards metanarratives" (p. xxiv) characterizes the postmodern era. Therefore, postmodernism criticizes metanarratives, universal ideologies and, master codes. Modern metanarratives including religion (Christianity), Enlightenment, Hegelianism, and Marxism, present general, absolute and universal claims about knowledge and truth, supposing the validity of their claims undoubtable. Postmodern theory has a totally pessimistic view towards metanarratives looking at them as damageable, criticizable, and finally negligible. Calinescu (1987) argued that Lyotard's various metanarratives of modernity share the notion of universal finality: essentially different, they are all based on a finalistic vision of universal history. So, Christianity as the story of humanity's final redemption from the original $\sin$ is constitutively modern and all modern stories of emancipation are secularized variations on its paradigm. Enlightenment as a modern metanarrative of progress through knowledge aims at the emancipation of humanity from evil ignorance. The speculative Hegelian story or Geist seeks to emancipate the mind from self-alienation through dialectics. Marxism aims at man's emancipation from exploitation through the revolutionary struggle of the proletariat (pp. 274-75).

Metanarratives are considered to be "large-scale theoretical interpretations purportedly of universal application" (Waugh, 1992, p. 1). They are hegemonic in terms of having faith in finality and absolute truth. They are of two kinds. The first kind is "mythical (traditional)", the second "projective (modern)". Legitimized in reference to its origin, Knowledge in traditional cultures refers to the primordial time when things came into being. According to Lyotard, in contrast to myths, the characteristic metanarratives of modernity legitimize knowledge "in terms not of the past but of the future." They legitimize knowledge and give a convincing answer to the question "What is knowledge ultimately good for?" (as cited in Calinescu, 1987, p. 274). Visà-vis postmodern "petites histories" (Calinescu, 1987, p. 275) modern metanarratives lose their universalism. Postmodernism's petites histories (little histories) versus modern grand histories are simply stories that have no claim of authenticity and so are favored by postmodernists. Postmodernism has no faith in finality inherent in modernism's metanarratives and subverts their horizons of emancipation. Instead, banality is favored. Under postmodern condition, everything is banalized.

Expressing their views on postmodernism, JeanFrançois Lyotard, Ihab Hassan, and Umberto Eco see it as a phenomenon recurring in every age. Lyotard, as Spencer (2001) mentions, considers postmodern condition as the one "occur[ing] again and again throughout history" (p. 163). To Hassan (1987) postmodernism is "a revenant, the return of the irrepressible" (p. 9). Similarly, to Eco (1984) it "is not 
a trend to be chronologically defined;" for, "every period has its own postmodernism just as every period would have its own mannerism" (p. 66). Critics discussing Finnegans Wake in the 1980s applied the term postmodernist to it, though for long it was included in the list of modernist works. Calinescu says that "James Joyce has been mentioned among the precursors of postmodernism ... particularly for Finnegans Wake as Ihab Hassan has repeatedly stated" (Calinescu, 1987, p. 300). Similarly, to Eco it is "already postmodern or at least initiates postmodern discourse" (1984, p. 66).

James Joyce (1882-1941) considered Finnegans Wake, his last novel, as "his masterpiece" (Lawrence, Seifter, \& Ratner, 1985, p. 434). The novel is divided into four books that are not named but numbered from I to IV. Book I, the longest book in the novel, consists of eight chapters; books II and III consist of four chapters; and the last book, the shortest book of the novel, has only one chapter. It is a record of the fantasies and dream-thoughts of a family whose head is Humphrey Chimpden Earwicker (H.C.E.). He has a wife named Anna (A.L.P.), who becomes the source of all life, a daughter, Isabel (Issy), and twin sons Shem and Shaun, who go by many names and who are all forces in opposition. In this novel, which has not much plot or characters to speak of, man's experience is viewed as fragmentary.

\section{DISCUSSION}

When Finnegans Wake first appeared in 1939, it marked "a radical change in Joyce's style and technique" (Litz, 1961, p. 76). It is a "comic version of the history of the Universe from Creation to Judgment day" (Goldman, 1968, p. 73) where Joyce explores the world history and interrogates its authority. Joyce's philosophy of art and life retains in itself those characteristics and qualities that enable us to label his frame of mind as postmodern. Finnegans Wake is Joyce's postmodern novel where we find the distrust of organized systems and ideologies. Indeed, "familiarity with Finnegans Wake is fundamental to the understanding of the postmodern world" (Booker, 1991, p. 191), for, it "registers the tensions between modernism and postmodernism shap[ing] the critical ideologies of postmodernism" (Mays, 1998, p. 22). Finnegans Wake, where the "unaccountable past" (Knowlton, 1998, p. 78) is revisited as it seems through "the eye of a noodle" (Joyce, 1942, p. 143 as cited in Knowlton, p. 78), reflects Joyce's incredulity towards metanarratives. In it the following list of metanarratives is defunct: Christianity (Christian redemption), Enlightenment, Hegelianism and Marxism.

\section{The Fall of Religion}

Postmodernism is mainly concerned with exploring the consequences of deity's disappearance, and so, the association between postmodernity and a secular view of the world becomes "automatic." The disappearance of deity opens the gates of contingency and unreason. Definitely, within the teleological concept of time inherent in the traditional conception of history, one cannot justify or even think of the death of deity: with regard to the "linear and irreversible progression" of time inherent in traditional history "each event in the sacred [traditional] history of Christianity is unique and will not be repeated" (Calinescu, 1987, p. 61).

Postmodernists do not reject history and tradition as modernists do. First, they believe that history is cyclical not teleological. Secondly, in their view historical facts are doubted for their "accessibility to us are entirely conditioned by textuality": we cannot know the past through its text, and thus, postmodernism calls for "a re-evaluation of and a dialogue" with the past (Hutcheon, 1988, p.16). Postmodernity, as we see in Finnegans Wake, "does not mean doing away with history" (Knowlton, 1998, p. 120) but a relationship to it that is a claim for "neither authentic reclamation nor dominating effacement" (Knowlton, 1998, p. 78). Postmodernists are tired of making everything new; they are for revision not omission.

In Finnegans Wake with its cyclical time, deity disappears. Consequently, the crisis of religion gives birth to a religion of crisis. Joyce unsettles every single certainty and induces existential anguish and despair. He is a heterodox in almost every field: in religion proper, in morals, in social and political thinking, and in aesthetics. Similar to the activity of the postmoderns, dreamt action in Finnegans Wake takes place in a post-apocalyptic framework. Joyce's dream of new anthropomorphosized gods in Finnegans Wake is enough to justify the death of deity as "necessary" (Hoffmann, 1963, p. 403).

Accordingly, Joyce challenges the authority of sacred texts, for, to him "writing itself is the generator of meaning" (Booker, 1991, p. 197). Religion throughout the world has been considered as the center of life. Christianity is teleological and all metanarratives are "secularized variations on its Paradigm" (Calinescu, 1987, p. 274). Joyce challenges the common feature of Lyotard's various metanarratives of modernity: universal finality. His incredulity towards metanarratives as "large-scale theoretical interpretations purportedly of universal application" (Waugh, 1992, p. 1) is manifest in what his characters say and do. Joyce draws upon postmodern devices such as black humor, kitsch, parody and pastiche to attack metanarratives, including Christianity. 
Northrop Frye placed Finnegans Wake in a select genre of which the Bible is the prototype (1957, p. 314) because the Bible plays such an important role in Joyce's novel. Joyce's frequent pastiche and parody are noticeable in Finnegans Wake in which "In the Buginning [beginning] is the woid [word; void]" (Joyce, 1942, p. 378) is a direct parody/pastiche of the Gospel of John. Furthermore, Joyce's suggestion is that one should "renove the bible", "scrape [his/her] soul", and "commit no miracles" (Joyce, 1942, p. 579), connoting that the Bible should be both removed and renewed.

Joyce's viewpoint is pluralistic and the foundation of all religions is his target. Once, Frank Budgen, Joyce's intimate friend, asked him why he had brought up his children without religious training. Answering Budgen, Joyce said that "but what do they [Joyce's children] expect me to do? ... . They can take their choice. I should never try to hinder or dissuade them" (as cited in Benstock, 1965, p. 102). Joyce had obviously made his choice: "the very presumption of the sacredness and authority of any text" (Booker, 1991, p. 197) is his target. He composes Finnegans Wake to rival the sacred books of the world: Finnegans Wake is Shem's "farced epistol to the hibruws" (Booker, 1991, p. 228), his "most moraculous jeeremyhead sindbook for all the peoples" (Booker, 1991, p. 229). Here Joyce puns upon the word hibruws. It connotes highbrows (ideal readers) as well as Hebrews (Hebrew people).

Finnegans Wake is a book whose devices and levels are multiple. What characters of this novel do aims at subverting tradition: religious, literary, and philosophical. Glugg (Shem), the devilish son of H.C.E. is deprived of learning, gnashing his teeth over books and devoting himself to low pursuits. He threatens to write an obscene book that is Finnegans Wake, where he will gossip about his parents and will call it confession (Booker, 1991, p. 236). By doing so, Shem subverts the holy institute of Confession. Furthermore, Shem lies dead in his grave but suddenly rises and makes a mock repentance. In a dexterous, bitter practice of black humor, Resurrection of mankind, a basic religious foundation shared by almost all religions, is derided: "For poor Glugger was dazed and late in his crave [grave], ay he, laid in his grave ... But low, boys low, he rises, shivering, with his spittyful eyes and his whoozebecome woice" (Joyce, 1942, p. 240). Elsewhere in the novel, the resurrecting power of divinity, of God! is shockingly parodied, for, Joyce endows Irish whiskey with Resurrecting Power!; in Finnegans Wake Tom Finnegan comes to life after someone cries out "Usqueadbaugham!" (Joyce, 1942, p. 24), i.e., whiskey.
Joyce's critique of religion is openly scabrous and scatological. $\mathrm{He}$ is a true liberal and the Old Testament is his other target. Somewhere else in the novel, Shem, an evil character, actually an atheist, places his dung in an urn for making "synthetic ink" and chants a psalm and thus shows his rudeness to the Old Testament, subverting another sacred text, David's Psalms (p. 185). Additionally, Shem's brother, Shaun, in his guise as Jaun, stands as a figure of religious and political oppression as well as a patriarchal authoritarian, produces for his sister Issy a list of proper behavior, and so, shows his incredulity towards religion. His advice begins with a pastiche (revision and parody) on the Ten Commandments: "First thou shalt not smile. Twice thou shalt not love. Lust, thou shalt not commix adolatry" (Joyce, 1942, p. 433). This pastiched list on the Ten Commandments also reflects Joyce's subversive view of the Old Testament.

The inhabitants of the postmodern society are "statusseeking" (Calinescu, 1987, p. 251) and indulge in status-seeking to excess. It is this uncontrolled desire that permits them to say anything they wish and imagine themselves in every imaginable situation so that they become schizophrenic. Similar to schizophrenics these indulgent inhabitants often confuse fact and fantasy and are under delusions. "The loss of the real and the appearance of the culture of hyperreality" (Baudrillard as cited in Selden and Widdoson, 1993, p. 180), where models both determine and undermine the real, are two sensationalist messages of postmodernism.

H.C.E., who thinks he is Jesus Christ, manifests a typical symptom of schizophrenia. Representing Jesus Christ (Joyce, 1942, p. 500), H.C.E. parodies the Crucifixion. Shockingly, the postmodern temper of the culture of hyperreality is compatible with what "the big cleanminded gaint H. C. E" (Joyce, 1942, p. 33) does in Finnegans Wake: on "an anxious seat [for] three and a hell [half] of hours' agony of silence" (Joyce, 1942, p. 75), H.C.E. dramatizes Christ's situation. Joyce's bitterly parodic attenuation of the Crucifixion and the consequent Christian Redemption demonstrated is manifest here. H.C.E. as a simulacrum of Christ, is a model as valid as the real, and yet mocks it. Furthermore, Last Supper is parodied in Finnegans Wake. Standing behind his bar, H.C.E. disposes drink to his twelve clients in a manner reminiscent of Jesus Christ serving bread and wine to the twelve disciples. As the novel shows, this subversive action aims at creating a visual as well as verbal parody of that event related by the apostles to the posterity. 
Joyce subverts religion out in Finnegans Wake, tearing the "nets" of "nationality", "language and religion" and flying by them (Joyce, 1969, p. 203). If Stephen in A Portrait "neither believes in [religion] nor disbelieves in it" (Joyce, 1969, p. 239), and is "not at all sure of it" (Joyce, 1969, p. 243), and if in Ulysses he still adheres to the doctrine of the soul (Parrinder, 1984, p. 13), H.C.E. in Finnegans Wake is quite sure of his blasphemy, and explicitly rejects Christianity, although it, in Stephen's terms, is "a symbol behind which are massed twenty centuries of authority and veneration" (Joyce, 1969, p. 203). Moreover, if in A Portrait God is portrayed as "a being infinitely good" whose loss will be "a loss infinitely painful" (Joyce, 1969, p. 128), in Finnegans Wake Joyce accuses Him of "the original sin, the creation of man" (Hassan, 1987, p. 147), and within the cyclical time of his novel justifies his disappearance. Then Finnegans Wake presents a world where deity is not in charge but "language itself" (Booker, 1991, p. 197). To Joyce, no book can be authoritative, not even the Bible or Finnegans Wake, because language is open to interpretation.

Finnegans Wake is a parody of "the serious in modern life and the western literary tradition" (Bowen, 1996, p. 262) in which "Scripture" is the target of Joyce's parody. For Joyce, who accuses God of committing the original sin, nothing is too abstract or too holy. In Finnegans Wake, by drawing upon "the technique of musically burlesquing" (Bowen, 1996, p. 264), Joyce hollows religious tradition deriding "the entire [divine] hierarchy" (Benstock, 1965, p. 103). In Finnegans Wake the names of Saints Peter and Paul appear as "Sinner Pitre and Sinner Poul" (Joyce, 1942, p. 192), therefore, completely conscious blasphemy can be understood here. Blasphemously, Joyce in Finnegans Wake attempts "both to parody and outdo the Christian idea and Scripture" (Booker, 1991, p. 197). Joyce, by assaulting the content of the Bible and other sacred texts, seeks desacralization.

The novel blurs the boundaries between fact and fantasy, and, in true postmodernist style, the everyday reality of the modern world becomes crazily mixed up with the fantastic and the supernatural. In Finnegans Wake's 'banalized' world, deep religious inclinations are "continually slapped down by impiety and derision" (Solomon, 1969, p. ix). To Joyce there is no difference between the texts of art and those of religion: both are constructed from the same raw materials, words. To him the Biblical words, like those of secular texts, are subject to the same uncertainty and multiple meanings.

\section{The Fall of Hegelianism and Marxism}

Hegel (1770-1831) established dialectics as a mode of modern philosophical inquiry. Dialectics supposes all phenomena to be in the process of perpetual change, contradiction, and development. Hegel uses dialectics to investigate the conditions of thought (idealism). Later on, Marx and Engles develop a materialist form of it (McQuillan, 2001, p. 92). As a method, dialectics seeks to reconcile two contradictions into a third one, synthesis. Hegelian dialectics consists of three parts done in a series of three-fold movements: a "thesis" being confronted by a contradictory "antithesis", and both being combined in a "synthesis", which in its turn becomes "the starting-point for a new triadic movement" (Findley, 1958, p. 69). Hegelian dialectics is a progressive phenomenon done in the chronological concept of time. The "most fundamental, powerful theme" in Hegel's philosophy is "the promise and fulfillment of reconciliation (versöhnunt)" (Spencer, 2001, p. 167). However, postmodernism celebrates "contingency, fragmentation, fissures, singularity, plurality, and ruptures" that defy reconciliation and achieving the perfect Hegelian synthesis. These gestures are "profoundly anti-Hegelian" (Spencer, 2001, p. 158).

Although Derrida sees Joyce as "the most Hegelian of writers" (Maharaj, 1997, p. 69), Finnegans Wake reflects his incredulity towards Hegelianism. Hegelian dialectics presupposes chronological time and is progressive. In contrast, in Joyce's last novel time is cyclic (McHale, 1987, p. 111), and there is no development at all, for the book's cyclic structure eliminates beginning, middle and ending. Finnegans Wake is the design of human history returning, ringlike, to its original condition, in the course of which "[t]he old order changeth and lasts like the first" (Joyce, 1942, p. 486). In it through all ages "the same roturns [returns]" (Ibid: 18) and "all that had been done, has yet to be done and done again" (Ibid: 194) and again. Joyce in his last novel presents "a world of essences" where there is "constant change but no growth and no development, no time sequence, and consequently no story" (Budgen, 1963, p. 349). Finnegans Wake, Joyce's "cyclewheeling history" (Joyce, 1942, p. 186), moves in cycles always repeating itself.

The composition of Finnegans Wake can be interpreted, on one level, as a critical exploration of Hegelian and Marxist dialectics. The nature of Hegelian dialectics, and Marx's adopted from Hegel's (Selden and Widdoson, 1993, p. 77), is progressive. Joyce, in the fate of his most talked figure, H.C.E., disfigures Hegelian dialectics, and so, dramatizes not 
a pattern of progression but of regression. In Finnegans Wake, H.C.E. represents the ultimate Hegelian synthesis, his sons (Shem and Shaun) thesis and antithesis. H.C.E. encompasses opposing, contradictory traits which "are isolated and separately embodied" in Shem and Shaun (Campbell \& Robinson, 1944, p. 19). As characters, Shem and Shaun are very much simpler than their father. Following the demise of H.C.E., Shaun and Shem are complimentary characters each of whom makes up half of the whole H.C.E.

The Joyce of Finnegans Wake announces the end of history by portraying H.C.E. as the ultimate synthesis of Hegelian dialectics in whom "all opposites" coincide and who "alone is complete" (Tindall, 1950, p. 86). In Finnegans Wake, the process of history is represented by the conflicts between Shem and Shaun (p. 80) who represent two poles of dialectics. In contrast to Hegelian dialectics, Joyce's novel shows an opposite tendency not of transcending antithesis towards the formation of a new synthesis, but of a gradual dissolution of the existing synthesis, H.C.E.

Indeed, the dialectic principle of Hegelian philosophy is itself a progressive principle, involving the conflict of antithetical forces and the resolution of that conflict in the form of a new synthesis, so that the former antithesis is transcended. Joyce reverses the fundamental premise inherent in Hegelian dialectics: the premise of progress. Joycean dialectics, in contrast to its Hegelian form, is an exprogressive process in which "the dialytically separated elements of precedent decomposition" will be used for "the very petpurpose [purpose] of subsequent recombination" (p. 614). Joyce reduces Hegelian dialectics to a vicious cycle where stasis governs not dynamics: Finnegans Wake "moves in vicious circles yet remews [renewes] the same" (Joyce, 1942, p. 134). So, within Finnegans Wake's cyclic time, HegelianMarxist dialectics becomes a closed system, and thus, Joyce subverts the Hegelian-Marxist model of dialectics.

Schematically, the movement of Hegelian dialectics can be represented as follows:

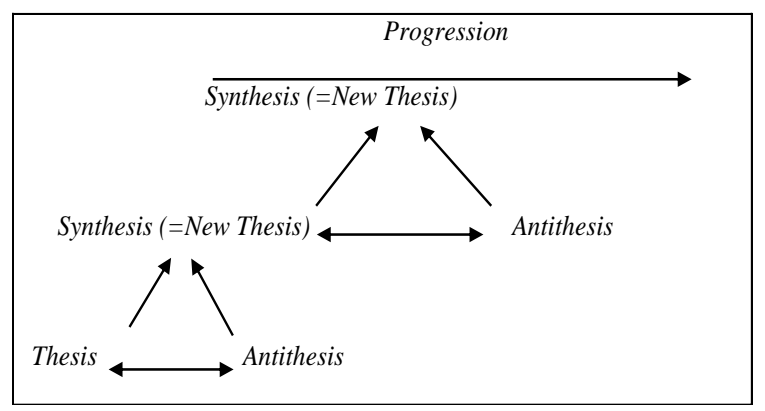

In contrast, the Schematic representation of Finnegans Wake's dialectics would be as follows:

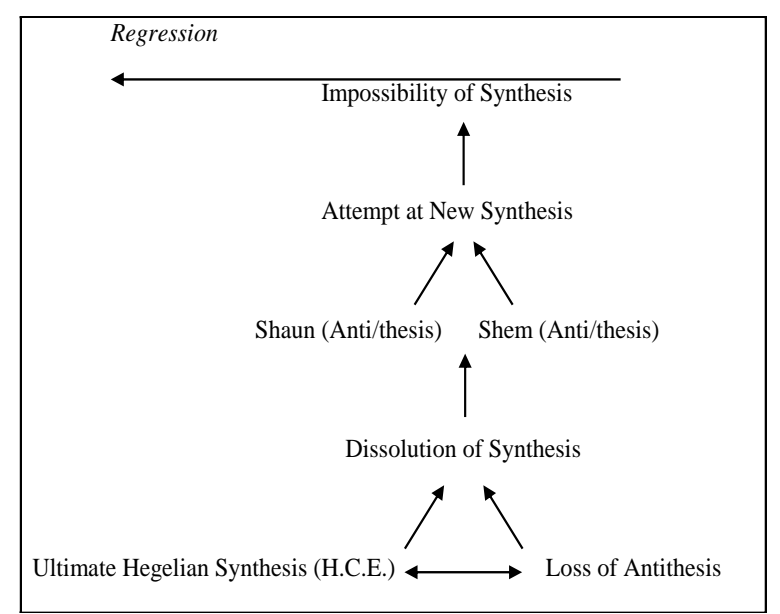

Definitely, Joyce was familiar with Hegel's and Marx's basic formula, the formula of dialectic thought. In Finnegans Wake he disfigures Hegelian dialectics, the very basis of Marxism and Hegelianism. Although the evolutionary social dialectic exists in Finnegans Wake, "it is not a Hegelian or Marxist class-based analysis" for historical evolution, Hegelian and Marxist, "is inexorably linear" (Miller, 1996, p. 84). Theodor Adorno believes that in Joyce's works "man is the product of history" (as cited in Hitchcock, 1999, p. 61); however, Joyce shows his incredulity towards the very basis of Marxism: Hegelian dialectics. Marxism is a very important modern project and its failure could be regarded as the failure of modernism. As Bernard Benstock argued in Joyce-again's wake: An analysis of Finnegans Wake (1965) "there is no reason to assume that Joyce was a Marxist, it is important to realize that Joyce was aware of the various political aspects of contemporary society spotlighted by Marx's sociological perspective" (p. 246).

However, Joyce's relation to Marxism as well as Hegelian dialectics is ironic and doubly-coded. Although we see Joyce's incredulity towards Hegelianism and Marxism, Joyce, as Levin puts it, proudly admits that his books are "devoted to the destinies of members of the lower middle class" (1960, p. 171); in Finnegans Wake's case to the life of HCE, an Irish pub-keeper. The result, however, is a Joyce who is, ironically, "more postmodernist than the postmodernists, more Marxist than the Marxists" (Hitchcock, 1999: 58), more Hegelian than Hegelians. The irony inherent in this incredulity is that, for all their differences, Marxists and Joyce do share a vision of more egalitarian forms of society. 


\section{The Fall of Enlightenment}

Enlightenment is another big project of modernism that aims at finding an answer to such questions as "What is there to be known?", and "How could one know it and with what degree of certainty?". In short, Enlightenment wants to rationalize everything. Enlightenment flourished in German academies of which narrative assumes "a consensus between the sender and addressee of a statement with truth-value $\ldots$ if it is cast in terms of a possible unanimity between rational minds" (Lyotard, 1984, p. xxiii). On the contrary, "postmodern existence is a continual process of trying to find meaning in the face of the knowledge that meaning is always relative and contingent" (Nicol, 1999, p. 46). Now, under postmodern condition, Enlightenment is finally at an end and its tenets are regarded as "exhausted", "dangerous", and "redundant" (Waugh, 1992, p. 1): the ultimate faith in rationality characteristic of the modernist project of Enlightenment has been replaced by an understanding that the world, as we see it in Finnegans Wake, is unknowable. Finnegans Wake "undermines the university's traditional practice of taking for granted that one is able to see through language [reason] to the truth. This novel is particularly subversive of university pedagogies because it presents a problem [that the university] cannot solve" (McGee, 2001, p. 23). In contrast to Enlightenment's emphasis on reason Finnegans Wake "dislocate[s]" (Joyce, 1942, p. 189) it. In this way, Joyce shows his incredulity towards Enlightenment of which the motto is "have courage to exercise your understanding" (Kant, 1992, p. 87) that is your reason.

Schizophrenic language, like schizophrenic thinking and behavior, is not stable and to grasp the meaning of its words or phrases or follow the chain of thoughts is often difficult. Thus, in this kind of language meaning is not transmitted and consensus is gone. Joyce's unconventional language in Finnegans Wake - of which vocabulary is completely new and the author does not provide us with the meaning of his neologisms although he claims that "The keys" to the novel are "Given" (Joyce, 1942, p. 628) -- is much invested with schizophrenia. Finnegans Wake's language is the language of "excessive specialization, approaching madness" presenting "an accurate picture of the dissolution of human reason" (Gilbert, 1963, p. 467).

Also, by representing academics devoted to low pursuits, Joyce mocks them, and so, undermines the role of academy, the center of Enlightenment. As in Gulliver's Travels, in Finnegans Wake we come across scholars devoting themselves to low missions.
A.L.P.'s letter scratched up from a midden-heap by a hen called Blinda becomes "the object of mockscholarship" (Burgess, 1965, p. 17), and, Finnegans Wake's serious-minded professor, accidentally puncturing a manuscript with his fork while eating his breakfast and then devoting his time to establishing the significance of the holes in the manuscript, offers a satiric view of the academics and their projects. The manuscript stands for the cultural heritage, and by having the professor puncturing it (Joyce, 1942, p. 26 \& pp. 190-194), Joyce mocks various branches of science (history, medicine, physics, and others), because their achievements are transmitted in written form (manuscript). Furthermore, Joyce has the professor expand his discussion so that the word 'hole' becomes the root of the word 'holy': in Joycean sense, the word holy would mean both sacred and full of holes!

\section{CONCLUSION}

Joyce pioneered techniques for undermining authority. In Finnegans Wake, he has freed himself from an allegiance to dead beliefs. The very method of the novel damns all dogma, scientific or religious, putting us to float in the limitless expanse of uncertainty and change. Finnegans Wake is a serious attempt "to transform the church into something more secular, humane and liberating" (Hofheinz, 1995, p. 150). By justifying the disappearance of God in Finnegans Wake, Joyce destroys the axle in relation to which everything was defined in the (pre)modern period and thus establishes relativity and anarchy. The political gesture of experimental writers underwent radical changes in the 1930s when a generation of modernists, Joyce among them, passed from "the age of innocence" into a new phase with a new historical consciousness regarded as "postmodern" (Wang, 1992, p. 64). Viewed as a single achievement, Joyce's writing recapitulates at least three generations of literary experiment to which Umberto Eco refers. To him both Dubliners and A Portrait are modern novels, Ulysses a modern novel on the verge of postmodern, Finnegans Wake a postmodern novel (Eco, 1984, p. 68).

Postmodernism involves the fragmentation and rebellion against modernist ideologies that impose essentializing identity, linear time schemes, and totalizing teleological metanarratives. The nature of postmodernism is interrogative and quizzical. In Finnegans Wake, Joyce leaps the stage of modernism into postmodernism. Finnegans Wake is one of the "early specimens of British Postmodernism" (Nicol, 1999, p. 295) where one finds almost all postmodern features: impersonations of other voices or pastiche, 
kitsch, schizophrenic language disorders, cyclical time, and incredulity towards metanarratives including religion, Hegelianism, Marxism, and Enlightenment. Similar to postmodernists, Joyce both hallows and hollows tradition. His postmodernist view towards the inherited cultural and historical achievement and his postmodernist-like revisiting of them in Finnegans Wake enable him to explore the world history and interrogate its authority. Dealing with "theories of Winestain [Einstein]" (Joyce, 1942, p. 149), Joyce's last polyphonic novel is "a kind of Logos of the Einsteinian vision of the universe" (Troy, 1963, p. 309) where Joyce shows his incredulity towards metanarratives and interrogates the notion of consensus. Joyce's view, concerning tradition in its variety, is different from the Modernist instinct for eradicating the past as embodied in the Futurist slogan "Down with moonlight" (Calinescu, 1987, p. 286), because Joyce helps us revisit 'the unaccountable past', as it seems through 'the eye of a noodle.'

\section{REFERENCES}

Benstock, B. (1965). Joyce-again's wake: An analysis of Finnegans Wake. Seattle and London: University of Washington Press.

Booker, M. K. (1991). Two modern myths of the Fall. Critique 32, 190-207.

Bowen, Z. (1996). Barth and Joyce. Critique, 37, 26169.

Budgen, F. (1963). Joyce's chapters of going forth by day. In Givens, S. (Ed.), James Joyce: Two decades of criticism (pp. 343-367). New York: The Vanguard Press.

Burgess, A., Ed. (1965). A shorter Finnegans Wake . London: Faber and Faber.

Calinescu, M. (1987). Five faces of modernity: modernism, avant-garde, decadence, kitsch, postmodernism. Duke University Press: Durham.

Campbell, J. \& Robinson, H. M. (1994). A skeleton key to Finnegans Wake. London: Faber and Faber.

Eco, U. (1984). Postmodernism, irony, the enjoyable (W. Weaver, Trans.). New York: Harcourt Brace Jovanovich.

Findley, J. N. (1958). Hegel: A re-examination. London: George Allen and Unwin LTD.

Frye, N. (1957). Anatomy of criticism. Princeton: Princeton University Press.

Gilbert, S. (1963). James Joyce. In S. Givens (Ed.), James Joyce: Two decades of criticism (pp. 450467). New York: The Vanguard Press.

Goldman, A. (1968). James Joyce. London: Routledge and KeganPaul.

Hassan, I. (1987). The postmodern turn: essays in postmodern theory and culture. Columbus: Ohio State University Press.
Hitchcock, P. (1999). Answering as authoring: or, Marxism's Joyce. Mosaic, 32, 55-69.

Hoffman, F. J. (1963). Infroyce. In S. Givens (Ed.), James Joyce: Two decades of criticism (pp. 390435). New York: The Vanguard Press.

Hofheinz, T. C. (1995). Joyce and the invention of Irish history: Finnegans Wake in context. Cambridge: Cambridge University Press.

Hutcheon, L. (1998). A poetics of postmodernism: History, theory, fiction. New York and London: Routledge.

Joyce, J. (1942). Finnegans Wake. London: Faber and Faber.

Joyce, J. (1969). A Portrait of the Artist as a Young Man. London: Penguin.

Kant, I. (1992). An answer to the question: What is Enlightenment? In P. Waugh (Ed.), Postmodernism: A reader (pp. 89-95). London: Edward Arnold Publishers.

Knowlton, E. (1998). Joyce, Joyceans, and the rhetoric of citation. Gainesville: Florida University Press.

Lawrence, K, Seifter, B., \& Ratner, L. (1985). The McGraw-Hill guide to English literature vol. 2. New York: McGraw Hill.

Levin, H. (1960). James Joyce: A critical introducetion. London: Faber and Faber, 1960.

Litz, A. W. (1961). The art of James Joyce: Method and design in Ulysses and Finnegans Wake. New York: Oxford University Press.

Lyotard, J. F. (1984). The postmodern condition: A report on knowledge ( $\mathrm{G}$. Bennington \& B. Massumi, Trans.). Manchester: Manchester University Press. (Original work published 1979)

Maharaj, S. (1997). Monkeydoodle: Annotating the anti-essay: After history. Art Journal, 56, 65-74.

Mays, M. (1998). Finnegans Wake, colonial nonsense, and postcolonial history. College Literature, 25, 20-34.

McGee, P. (2001). Joyce beyond Marx: History and desire in Ulysses and Finnegans Wake. Gainesville: Florida University Press.

McHale, B. (1987). Postmodernist fiction. London and New York: Routledge.

McQuillan, M. (2001). Paul de Man. London and New York: Routledge.

Miller, W. L. (1996). Male and female creativity in James Joyce's Finnegans Wake. Sydney: University of New South Wales Press.

Nicol, B. (1999). Reading paranoia: paranoia, epistemophilia and the postmodern crisis of interpretation. Literature and Psychology, 45, 44-62.

Parrinder, P. (1984). James Joyce. New York: Cambridge University Press.

Selden, R. \& Widdoson, P. (1993). A reader's guide to contemporary literary theory. New York: Harvester Wheatsheaf. 
Solomon, M. C. (1969). Eternal geomater: The sexual universe of Finnegans Wake. Carbondale, IL: Southern Illinois University Press.

Spencer, L. (2001). Postmodernism, modernity, and the tradition of dissent. In S. Sims (Ed.), The Routledge companion to postmodernism (pp. 158-169). London and New York: Routledge.

Tindall, W. Y. (1950). James Joyce, his way of interpreting the modern world. New York: Scribner.
Troy, W. (1963). Notes on Finnegans Wake. In S. Givens (Ed.), James Joyce: Two decades of criticism (pp. 302-318). New York: The Vanguard Press.

Wang, J. (1992). To wielderfight his penisolate war: The lover's discourse in postmodernist fiction. Critique, 34, 63-79.

Waugh, P. (1992). Postmodernism: A reader. London: Edward Arnold Publishers. 